\title{
Pendidikan Islam Berwawasan Multikultural; Sebuah Upaya Membangun Pemahaman Keberagamaan Inklusif pada Umat Muslim
}

\author{
Muhammad Aji Nugroho \\ Program Doktor UIN Walisongo Semarang \\ khoira2013@gmail.com \\ DOI: 10.18326/mudarrisa.v8i1.31-60
}

\begin{abstract}
Abstrak
Masyarakat majemuk bagian dari sunnatullah, yang memberikan sumbangan besar bagi munculnya ketegangan, konflik dan krisis sosial, sehingga tuntutan reformasi sistem pendidikan Islam yang terkesan sebagai alat indoktrinasi yang anti realitas multikultural perlu dilakukan agar mampu menciptakan tatanan kehidupan masyarakat yang damai, harmonis, menjunjung tinggi nilai kemanusiaan, dan mampu beradaptasi dengan berbagai golongan yang berbeda namun tetap tidak terlepas dari akar budaya, agama, jati dirinya, dalam masyarakat yang plural sebagai insān kamīl (manusia paripurna). Pendidikan Islam berwawasan multikultural hadir bertujuan untuk: 1) menghapus prasangka "prejudice", dan sekaligus untuk melatih dan membangun karakter siswa agar mampu bersikap demokratis, humanis dan pluralis; 2) membangun pemahaman keberagaman siswa yang inklusif sehingga mampu mengeliminir jarak sosial antar peserta didik yang berbeda agama guna terciptanya persaudaraan sejati; 3) mengajarkan bagaimana cara hidup ditengah pluralisme bangsanya; 4) memberikan perlindungan dari diskriminasi; 5) mengakui dan meng-akomodasi kebebasan individu kelompok minoritas, seperti berbicara, berkelompok, menjalankan agama dan sebagainya yang berakar dari nilai-nilai kebebasan, kesetaraan dan demokrasi, sehingga hak-hak kultural minoritas dapat terakomodasi dengan baik, yang berarti bahwa setiap peserta didik mempunyai hak
\end{abstract}


Mudarrisa, Jurnal Kajian Pendidikan Islam, Vol. 8, No. 1, Juni 2016: 31-60

untuk masuk dalam budaya tertentu, ikut dibentuk dan membentuk budaya itu.

Plural society is a part of sunnatullah, which contributed greatly to the emergence of tension, conflict and social crisis, so that the demands for reform Islamic education system that impressed as a indoctrination of anti realities of multicultural needs to be done on creating a social order that is peaceful, harmonious, uphold humanity, and able to adapt to different groups but still cannot be separated from the roots of culture, religion, identity, in pluralistic society as insān kamīl. Islamic Education aims to present a multicultural conception: 1) remove the prejudice, and to train and build the character of students to be able to be democratic, humanist and pluralist; 2) build understanding of the diversity of students' inclusive to eliminate the social distance between learners of different religions to create true brotherhood; 3 ) teaches how to live amid pluralism nation; 4) providing protection from discrimination; 5) recognizes accommodation individual freedom of minority groups, such as talking, group, practice religion and so on are rooted in the values of freedom, equality and democracy, so cultural rights of minorities can be accommodated properly, which means that every student has the right to enter into a particular culture, are formed and participate in shaping the culture.

Kata kunci: pendidikan Islam, pendidikan multikultural, pendidikan Islam berwawasan multikultural

\section{Pendahuluan}

Pendidikan menjadi alat penting bagi perkembangan suatu bangsa, secara otomatis kualitas dari peserta didik mulai dari (kognisi, afeksi, hingga psikomotorik) tergantung pada pendidikan yang didapatkannya. Maka bagi pendukung humanistik pendidikan diartikan sebagai proses yang memberikan kebutuhan bagi pertumbuhan dan integritas pribadi seseorang secara bebas dan bertanggung jawab (Jhon D., 1988:5). Selain 
itu, masa depan bangsa terletak dalam tangan generasi muda, mutu bangsa yang dikemudian hari bergantung pada pendidikan yang dikecap oleh peserta didik, terutama melalui pendidikan formal yang diterima di sekolah, dan apa yang dicapai disekolah ditentukan oleh kurikulum sekolah itu, dan dengan menguasai pendidikan akan memegang nasib bangsa dan negara (Nasution, 2003:1). Dengan demikian, integritas bangsa tentang kerukunan "anti dominasi dan konflik" bisa terjaga melalui keberhasilan pendidikan yang mendekatkannya pada realitas multikultural yang di hadapi setiap peserta didik dalam kehidupannya.

Pendidikan menjadi sarana rekayasa yang dapat mengarahkan seseorang untuk mengikuti dan menyakini kebenaran yang diperoleh melalui kerangka berfikir keilmuan yang dihasilkannya, menjadi sarana paling ampuh untuk pembentukan karakter pribadi seseorang serta propaganda nilai-nilai budaya yang dianggap penting bagi penggagas keilmuan tersebut (Riyadi dalam Khoiriyah, 2013:x-xi). Di samping itu, pendidikan sebagai institusi sosial memiliki fungsi sebagai proses perubahan sosial yang mampu mengakomodir karakter sosial yang dimiliki masyarakat, yang bukan sekedar transfer informasi tentang ilmu pengetahuan dari guru kepada murid, melainkan suatu proses pembentukan karakter yang memiliki tiga misi utama yaitu; pewarisan pengetahuan (transfer of knowledge), pewarisan budaya (transfer of culture), dan pewarisan nilai (transfer of value). Sebab itu pendidikan dipahami sebagai suatu proses transformasi nilai-nilai dalam rangka pembentukan kepribadian dengan segala aspek yang dicakupnya (Syahidin, 2009:2). 
Namun dalam pendidikan Islam proses pembentukan karakter tersebut dianggap terhambat dalam mendukung kerukunan antar umat beragama, hal ini disebabkan oleh dua hal; Pertama, pendidikan Islam hanya dilakukan secara simbolik ritualistik, tanpa memikirkan korelasi antara simbol-simbol agama dengan realitas yang ada dalam masyarakat. Kedua, pendidikan Islam mengabaikan tiga komponen dasar pendidikan; Intelektual atau kognitif, emosional atau afektif, dan psikomotorik (Yusuf, ed., 2008:2). Selain itu, menurut Wahid (2009:146), terdapat empat faktor penyebab ketidaktuntasan pendidikan Islam dalam menumbuhkan semangat multikulturalitas dan pluralitas pada peserta didik. Pertama, penekanan pendidikan hanya pada proses transfer ilmu agama ketimbang proses transformasi nilai dan moral keagamaan pada anak didik. Kedua, sikap bahwa pendidikan agama hanya sebatas pelaksanaan formal dari kurikulum. Ketiga, kurangnya penekanan penanaman nilai moral yang mendukung kerukunan antar agama. Keempat, kurangnya perhatian untuk mempelajari agama lain. Wajar bila dari hasil penelitian di atas disimpulkan bahwa pendidikan Islam anti terhadap realitas multikultural dan cenderurng ekslusif.

Selama ini, konflik antar agama yang telah terjadi, dipicu oleh perbedaan doktrinal yang dipelihara sebagai keyakinan yang absolut (Sumartana, 2005:76-79), yang kemudian di dukung faktor-faktor yang melatar belakanginya, di antaranya: 1) Eksklusivitas dari pemimpin dan penganut agama; 2) sikap tertutup dan saling curiga; 3) Keterkaitan yang berlebih-lebihan terhadap simbol-simbol agama; 4) agama menjadi alat legitimasi; 5) kondisi politik, sosial dan ekonomi (Sumartana, 2005:33- 
37). Hal ini menjadi bertolak belakang dengan misi agama sebagai panduan moralitas manusia untuk menemukan nilai-nilai kemanusiaannya, membangkitkan kesadaran betapa penting dan bernilainya kehadiran manusia yang lain, yang memiliki perbedaan, dan keunikan tersendiri, pada poin ini lah pendidikan Islam berada pada persimpangan yang membingungkan ketika mengalami benturan antara menguatkan doktrin atau melemahkan solidaritas, yang kemudian memunculkan kesan menjauh dari realitas masyarakatnya (Qodir, 2007:8-9). Dari urain ini bisa dimengerti bahwa terdapat proses yang yang salah dalam pendidikan Islam, sehingga tidak mampu melihat kebenaran diluar kebenarannya yang menjadi panduan moralitas baginya.

Sementara itu, Islam sebagai agama yang dinamis, harmonis, toleran sebagai sumber persatuan umat manusia (universal humanity) terkubur oleh tajuk-tajuk berita dan slogan-slogan (sebagian kelompok) yang mengancam perbedaan dan keragaman umat manusia yang ada, sebagaimana kasus-kasus kekerasan yang terjadi (Esposito, 2004:246). Hal ini disebabkan ajaran Islam cenderung dipahami secara normatif yang hanya berisi tumpukan dogma yang kaku dan cerderung formalis, antara teks dan konteks, antara wilayah normatif dan historis tidak terjembatani dengan baik, sehingga terlalu kering (Muqowwim, 2007:3132). Oleh karena itu, harus selalu ada upaya kontekstualisasi teks melalui pendidikan Islam berwawasan multikultural dengan pemahaman yang lebih komprehensif dalam dinamika kehidupan yang majemuk, sehingga mampu menjawab problem yang ada di bumi. Inilah yang menjadi 
motivasi penulis untuk mengkaji tema di atas menjadi kajian yang terstruktur dan progresif.

\section{Metode Penelitian}

Jenis penelitian ini adalah penelitian kualitatif yang menitik beratkan pada penelitian kepustakaan (library research) dengan mengkaji teks alQur'an, hadis, buku-buku, dan naskah yang bersumber dari khazanah kepustakaan yang relevan dengan permasalahan yang diangkat dalam penelitian ini (Efendy, 1989:192). Sumber data yang digunakan terbagi menjadi dua bentuk primer dan sekunder. Data primer adalah buku yang dijadikan pegangan utama berupa kajian pendidikan Islam dan pendidikan multikultural. Sedangkan data sekunder adalah buku buku yang masih dianggap relevan dengan kajian penelitian (Arikunto, 1993:131). Metode analisis yang digunakan adalah analisis diskriptif, yang difungsikan untuk menentukan hubungan antar kategori dengan yang lain, melalui interpretasi yang sesuai dengan peta penelitian yang dibimbing oleh permasalahan yang sedang di kaji dalam tujuan penelitian, untuk mewujudkan kontruksi teoritis sesuai dengan permasalahan penelitian (Surakhmand, 1980:93).

\section{Makna dan Karakteristik Pendidikan Islam}

Pendidikan Islam dalam bahasa Arab disebut tarbiyah islamiyah. Tarbiyah berasal dari tiga kata: 1) rabā, yarbū, artinya bertambah dan tumbuh; 2) rabia, yarbā berarti menjadi besar; dan 3) rabba, yarubbu, memperbaiki, menuntun, menjaga, dan memelihara (an-Nahlawi, 
1989:30-31). Dari tiga kata asal tersebut Abdurrahman al-Baniy (1989, hlm. 32) menyimpulkan, tarbiyah islamiyah mengandung empat unsur; a) memelihara kondisi fitrah manusia; b) mengembangkan seluruh potensi dan kesiapan yang bermacam-macam; c) mengarahkan seluruh fitrah (pembawaan baik) dan potensi manusia menuju pada kebaikan dan kesempurnaan yang layak (Islami); dan d) proses itu dilaksanakan secara bertahap.

As-Syaibani (1979:399) mendefinisikan pendidikan Islam sebagai proses mengubah tingkah laku individu pada kehidupan pribadi masyarakat, dan alam sekitar dengan cara pengajaran sebagai suatu aktivitas asasi dan sebagai profesi diantara profesi-profesi asasi dalam masyarakat. Sementara itu Marimba (1980) mendefinisikannya dengan bimbingan jasmani dan rohani, berdasarkan hukum-hukum agama Islam menuju kepada terbentuknya kepribadian utama menurut ukuran-ukuran Islam. Sedangkan Tafsir (2005:45) mendefinisikan pendidikan Islam sebagai bimbingan yang diberikan oleh seseorang agar ia berkembang secara maksimal sesuai dengan ajaran Islam.

Pendidikan Islam merupakan bagian bagian dari sistem kehidupan umat Islam dari sistem kehidupan umat Islam dan mempunyai tujuan yang menjadi bagian dari tujuan hidup manusia menurut Islam (Langgulung, 1995:5). Oleh sebab itu wajar bila pendidikan Islam harus diposisikan sebagai media untuk mencapai tujuan tersebut (Azra, 1999:7). Pendidikan Islam memiliki dua fungsi utama, yaitu; 1) fungsi konservatif pendidikan yaitu mewariskan dan mempertahankan cita-cita dan budaya suatu masyarakat pada generasi penerus, 2) fungsi progresif 
pendidikan yaitu bagaimana aktifitas pendidikan dapat memberikan bekal ilmu pengetahuan dan pengembangannya, penanaman nilai-nilai dan bekal keterampilan mengantisipasi masa depan, hingga generasi penerus mempunyai bekal kemampuan dan kesiapan untuk menghadapi tantangan masa kini dan mendatang (Ismail, ed., 2001:234).

Dengan demikian tugas pendidikan Islam tidak berhenti pada sekedar menumbuhkembangkan potensi peserta didik, lebih dari itu pendidikan Islam mengemban misi mengarahkan, dan membentuk peserta didik sejalan dengan tujuan hidup manusia sehingga terbentuknya kepribadian yang dilengkapi dengan sejumlah kompetensi sesuai nilainilai yang diajarkan dalam Islam guna menunjang pencapaian "sukses menjadi khalifah Allah di persada bumi” sebagai salah satu bentuk tujuan hidup manusia menurut ajaran Islam (Asifudin, 2009:18-19). Dua sasaran itu "menumbuh-kembangkan potensi dan mengarahkannya sesuai dengan misi agama Islam" merupakan salah satu dari karakteristik atau ciri khas dari Pendidikan Islam yang bertujuan untuk membentuk insān kāmil "manusia paripurna", adapaun karakteristik yang lainnya sebagaimana diuraikan dibawah ini.

Pendidikan Islam memiliki cukup banyak karakteristik, antara lain; 1) mengedepankan tujuan agama dan akhlak yang berorientasi pada pendidikan tauhid dan penanaman nilai-nilai berdasarkan al-Qur'an dan Hadis; 2) selaras dengan fitrah manusia termasuk berkenaan dengan pembawaan, bakat, jenis kelamin, potensi, dan pengembangan psikofisik; 3) merespon dan mengantisipasi kebutuhan nyata peserta didik dan masyarakat, serta mengusahakan solusi terkait dengan masa depan 
perubahan sosial yang terjadi secara terus menerus; 4) bersifat kreatif dan inovatif mendorong penggunaan metode yang dinamis fleksibel, dan membuat peserta didik belajar didorong oleh kesadaran dan hati senang, termasuk dalam menghadapi pelajaran-pelajaran agama; 5) materinya realistik, terjangkau, disusun secara runtut sesuai dengan psiko-fisik, tingkat dan jenjang peserta didik; 6) mengembangkan keseimbangan dan proporsionalitas antara pengembangan intelektual, emosional, dan spiritual, juga antara yang bersifat teoritik dan memecahkan masalah kehidupan; 7) menghindarkan peserta didik dari pemahaman dikotomik terhadap ilmu pengetahuan agama dan ilmu-ilmu yang lain, sekaligus menghindarkan pemahaman parsial yang membuat peserta didik bersikap ekstrim (Al-Toumy, 1979:519-522).

\section{Mengintegrasikan Multikulturalisme dalam Pendidikan}

Istilah multikultural yang terdiri dari dua kata, multi dan kultural. Multi berarti plural/bermacam-macam atau beragam, sedangkan kultural berasal dari kata cultural yang berarti kebudayaan, multikultural berarti beraneka ragam kebudayaan. Secara sederhana multikulturalisme dapat dikatakan pengakuan atas pluralisme budaya sebagai suatu proses internalisasi nilai-nilai di dalam suatu komunitas (Tilaar, 2004:82, 179). Ahli posmodernisme, mengajukan pengertian multikultural dengan mengontraskannya dengan monokultural (budaya yang homogen). Dengan demikian istilah multikultural mengacu pada banyak kebudayaan (heterogen), yang kemudian membentuk identitas satu kebudayaan (Lubis, 2006:170-171). Farida (2011:67) dengan mengutip pendapat 
Parsudi Suparlan, berpendapat akar kata dari multikultural adalah kebudayaan yang dilihat dari fungsinya sebagai pedoman bagi kehidupan manusia. Dalam konteks pembangunan bangsa, istilah multikultural ini telah membentuk suatu ideologi yang disebut multikulturalisme. hal ini dikarenakan penambahan kata isme dalam multikulturalisme melukiskan sebuah cara pemahaman dalam memahami perbedaan dengan prespektif kebudayaan.

Secara etimologis, multikulturalisme dibentuk dari kata multi (banyak), kultur (budaya), dan isme (aliran atau paham), yaitu sebuah pengakuan akan kehidupan manusia yang mempunyai kebudayaan beraneka ragam dengan segala keunikannya, yang dilukiskan sebagai kearifan melihat keaneragaman budaya sebagai realitas fundamental dalam kehidupan bermasyarakat, yang memunculkan kesadaran bahwa keaneragaman dalam realitas dinamik kehidupan adalah suatu keniscayaan yang tidak bisa ditolak, diingkari, apalagi dimusnahkan (Mahfud, 2006:75,103). Menurut Baidhawy (2005:4) multikulturalisme adalah pandangan bahwa setiap kebudayaan memiliki nilai dan kedudukan yang sama dengan setiap kebudayaan lain, sehingga setiap kebudayaan berhak mendapatkan tempat sebagaimana kebudayaan lainnya. Sedangkan Tilaar (2004:173) berpendapat multikulturalisme adalah pengakuan yang sama atau kesederajatan atas keberbagaian perbedaan baik dalam hal agama, suku, atau budaya. Menurutnya, sekurang-kurangnya ada tiga hal yang mendorong berkembangnya multikulturalisme yaitu HAM, globalisasi, dan proses demokratisasi. 
Kymlicka $(2002 ; 13)$ mengatakan bahwa istilah multikulturalisme mencakup berbagai bentuk pluralisme budaya yang berbeda, masingmasing memiliki tantangan sendiri-sendiri,. mencakup sejumlah kelompok sosial non etnis yang karena berbagai alasan yang dikecualikan atau dikesampingkan dari aliran utama masyarakat, seperti; penyandang cacat, para homoseksual dan lesbian, perempuan, kelas pekerja, atheis dan komunis. Menurut Kymlicka, (2003:10-26) multikultulturalisme memberikan perlindungan dari diskriminasi, mengakui dan mengakomodasi kebebasan individu kelompok minoritas, seperti kebebasan berbicara, berkelompok, menjalankan agama yang berakar dari nilai-nilai kebebasan, kesetaraan dan demokrasi, sehingga hak-hak kultural minoritas dapat terakomodasi dengan baik. Dengan demikian masyarakat multikultural menerima dan menghargai berbagai perbedaan serta memasukkan pengaruh budaya yang terpinggirkan selama ini sebagai salah satu unsur budaya yang diakui ikut mempengaruhi budaya secara keseluruhan (Kymlicka, 2002:25). Dari pengertian di atas, disimpulkan bahwa multikulturalisme adalah sistem keyakinan dan perilaku yang mengakui dan menghormati kehadiran semua kelompok yang beragam dalam suatu organisasi atau masyarakat, dan mendorong untuk berkontribusi dalam konteks budaya inklusif dalam masyarakat.

Urgensi mengintegrasikan multikulturalisme dalam pendidikan, karena persoalan hidup dan kehidupan manusia, dan seluruh proses hidup dan kehidupan manusia adalah proses pendidikan (Muhaimin, 2004:30). Oleh karena itu pendidikan multikulturalisme, dinilai dapat mengakomodir segala perbedaan dalam kesederajatan, sebagai sebuah 
konsep yang mampu meredam konflik vertikal dan horizontal dalam masyarakat yang heterogen dimana tuntutan akan pengakuan dan eksistensi dan keunikan budaya kelompok etnis sangat wajar terjadi (Khoiriyah, 2013:218). Selain itu, pendidikan multikultural harus mampu menciptakan lingkungan yang kondusif bagi pengakuan akan hak asasi manusia. UNESCO menegaskan bahwa hak asasi manusia merupakan jaminan bagi keaneragaman budaya yang merupakan penghargaan terhadap martabat manusia (Ujan dkk, 2009:54-55). Maka, pendidikan multikultural perlu dikembangkan sehingga mencapai kehidupan yang damai, harmonis, dan menjunjung tinggi nilai kemanusiaan.

Baidhawy (2005:5) menjelaskan pendidikan multikultural adalah suatu cara untuk mengajarkan keragaman (teaching diversity), yang menghendaki rasionalisasi etis, intelektual, sosial dan pragmatis secara inter-relatif, yang mengajarkan ideal-ideal inklusivisme, pluralisme, dan saling menghargai dengan mengintegrasikan studi tentang fakta, sejarah, kebudayaan, nilai, struktur, prespektif, dan kontribusi semua kelompok kedalam kurikulum sehingga dapat membangun pengetahuan yang lebih kaya, kompleks, dan akurat tentang kondisi kemanusiaan di dalam dan melintasi konteks waktu, ruang dan kebudayaan tertentu. Menurut Zamroni (20013:120) pendidikan multikultural merupakan suatu bentuk reformasi pendidikan yang bertujuan untuk memberikan kesempatan yang setara bagi semua siswa tanpa memandang latar belakangnya, sehingga semua siswa dapat meningkatkan kemampuan secara optimal sesuai dengan ketertarikan, minat dan bakat yang dimiliki. 
Banks (2010:16-17), memaknai pendidikan multikultural sebagai sebuah konsep, ide atau falsafah yang merupakan rangkaian kepercayaan (set of believe) dan penjelasan untuk mengakui dan menilai pentingnya keragaman budaya didalam membentuk gaya hidup, pengalaman sosial, identitas pribadi, kesempatan-kesempatan pendidikan dari individu, maupun kelompok, melalui 6 faktor yang menjadi sumber pertimbangan yaitu; a) gender, b) race atau etnic, c) social class, d) religion, e) exceptionality, dan f) other variables. Race (2011:5-8) mendiskripsikan evolusi pendidikan plural-multikultural atau multibudaya ke dalam empat fase. Pertama, upaya untuk mempersatukan kajian-kajian etnis pada setiap kurikulum. Kedua, menerapkan persamaan pendidikan melalui reformasi keseluruhan sistem pendidikan. Ketiga, menuntut perubahanperubahan mendasar dalam lembaga pendidikan bagi kelompokkelompok marginal, seperti perempuan, orang cacat, homo dan lesbian. Keempat, Gerakan reformasi mengupayakan transformasi proses pendidikan dan lembaga-lembaga pendidikan pada semua tingkatan sehingga semua murid, apapun ras atau etnis, kecacatan, jenis kelamin, kelas sosial dan orientasi seksualnya akan menikmati kesempatan yang sama untuk menikmati pendidikan.

Menurut Tilaar (2004:216-221), terdapat tiga prinsip pendidikan multikultural; Pertama, pendidikan multikultural didasarkan pada pedagogik kesetaraan manusia (equity pedagogy). Kedua, pendidikan multikultural ditujukan kepada terwujudnya manusia Indonesia yang cerdas dengan mengembangkan pribadi Indonesia yang menguasai ilmu pengetahuan dengan sebaik-baiknya. Ketiga, prinsip globalisasi tidak 
perlu ditakuti apabila bangsa ini mengetahui arah serta nilai-nilai baik dan buruk yang dibawanya. Dari tiga prinsip ini sudah dapat menggambarkan bahwa arah dari wawasan multikultural-isme melalui pendidikan multikultural adalah untuk menciptakan manusia yang terbuka terhadap segala macam perkembangan zaman dan keragaman berbagai aspek dalam kehidupan modern, dapat menghapus streotipe, sikap dan pandangan egoistik, individualistik dan eksklusif di kalangan anak didik. senantiasa tumbuh pandangan komprehensif terhadap yang lain.

\section{Sinergitas Islam dan Pendidikan Multikultural}

Islam memiliki misi rahmatan lil 'àlamīn bagi kehidupan sosial, setidaknya dari misi ini jika ditelusuri dalam ajaran Islam, subtansi "multikultural" bukanlah hal yang baru. Esensi multikultural yang menghendaki pengakuan dan penghormatan terhadap orang lain yang berbeda ras, suku, bahasa, adat istiadat, bahkan agama sekalipun, sebagaimana Islam menegaskan bahwa keaneragaman manusia (jenis kelamin, suku, bangsa, dll) dalam kehidupan adalah sunnatullah atau alamiah sebagaimana yang terurai di dalam Qs. Al-Hujurat 49:13, dalam ayat ini paling tidak bisa diketahui dengan keragaman manusia tersebut, manusia di harapkan mampu menciptakan kedamaian dengan saling mengenal dan berlomba dalam kebaikan "istabiq al-khairāt". Fakta ayat ini menyebutkan bahwa Islam memperkokoh toleransi dan memberikan aspirasi terhadap multikulturalisme, dan menegaskan terdapat hubungan yang kuat antara nilai-nilai (agama) dalam kebangsaan dengan dilandasi 
semangat humanitas dan universalitas Islam. Hal ini merupakan wujud dari posisi Islam sebagai agama terbuka (open religion) yang menghendaki munculnya sikap inklusif sebagai bentuk justifikasi keterbukaan Islam terhadap realitas kemajemukan manusia (Helmanita, 2004:12-14).

Konsep 'adl (keadilan), syūra' (musyawarah), dan musawā (persamaan) merupakan upaya Islam untuk membangun keadilan sosial dalam menghargai dan menghormati keberagaman manusia melalui demokrasi. Bahkan dalam hal keadilan sebagaimana yang dikutip Sukron Kamil dari Ibnu Taimiyah bahwa Tuhan Mendukung kekuasaan yang adil meskipun kafir, dan tidak mendukung kekuasaan yang zalim meskipun Islam (Kamil, 2004:18). Selain itu, Islam meyakini bahwa semua manusia adalah sama derajatnya karena berasal dari satu jenis yang sama, yaitu Adam, dan ketinggian derajat manusia hanya dihitung dari kualitas ibadahnya dan bermanfaat atau tidaknya seseorang bagi dirinya, masyarakat, dan bangsanya, tidak ada ruang bagi siapapun untuk merendahkan martabat seseorang dengan status sosial yang dimilikinya, memperbudak, diperbudak, membunuh dan dibunuh oleh orang lain, karena itu semua adalah hak prerogatif Allah (Kusmana, 2008:47-49). Oleh sebab itu, merusak, menghina, dan mencaci tempat ibadah, tatacara, ajaran, kebudayaan agama dan kelompok lain karena perbedaan yang muncul merupakan perbuatan yang melanggar ajaran Agama.

Munculnya kasus kerusuhan dan kekerasan atas nama agama merupakan cermin kegagalan dalam pendidikan Islam, karena tidak ada satupun ajaran agama (termasuk Islam) mendorong dan menganjurkan 
pengikutnya untuk melakukan tindak kekerasan (violence) dan kerusuhan (unrest) terhadap pengikut agama lain. Bila hal di atas dikaitkan dengan pendidikan Islam, maka pendidikan Islam harus mampu; 1) menciptakan kesalehan sosial dan bukan hanya kesalehan individual; 2) membentuk peserta didik menjadi masyarakat yang humanis; 3) mencetak individu yang dapat menyerap cakrawala; 4) mencetak peserta didik yang cerdas, kreatif, dan aktif membaca problem realitas di sekitarnya untuk kemudian memberikan alternatif pemecahan; dan 5) menampilkan wajah agama yang damai (Muqowim, 2007:17-20).

Islam yang inklusif, pluralis, multikulturalis, dan humanis dimaknai dengan; 1) dapat menerima pendapat dan pemahaman agama lain yang memiliki basis ketuhanan dan kemanusiaan; 2) menerima adanya keragaman ekspresi budaya yang mengandung nilai-nilai kemanusiaan dan keindahan;dan 3) mengakui pentingnya nilai-nilai kemanusiaan, seperti menghormati hak asasi orang lain, peduli terhadap orang lain, berusaha membangun perdamaian dan kedamaian bagi seluruh umat manusia, saling mengasihi dan menyayangi, peduli terhadap orang lain yang berbeda suku dan agama yang bukan berarti harus mengikuti adat istiadat atau keyakinan serta agama mereka, yang mengikat manusia untuk senantiasa berbuat baik (Yusuf, ed., 2008:19). Pernyataan ini menegaskan misi Islam tentang rahmatan lil 'àlamīn melalui agama dan pendidikan multikultural dapat terealisasikan dan berjalan dengan harmonis di tengah masyarakat yang multikultural dan majemuk, sehingga dapat menemukan kedamaian yang selaras dengan tuntunan Agama. 


\section{Pendidikan Islam Berwawasan Multikultural}

Pendidikan Islam berwawasan multikultural diwujudkan dalam rangka memenuhi cita ideal Islam shāliḥ li kulli zamān wa makān, yaitu; tercapainya bentuk dan aspek kemanusiaan secara menyeluruh, baik lahir maupun batin, dengan mengapresiasi secara positif dan kritis terhadap perkembangan dan kebutuhan zaman, sehingga Islam sebagai agama yang sesuai dengan situasi dan kondisi tidak menjadi kering karena penetrasi global yang terus berkembang (Barizi, 2011:106). Maka menjadi tugas pendidikan Islam untuk menderekonstruksi sistem pendidikan yang mengarah pada humanis dan antri diskriminasi, yang tidak hanya diacu ke arah ritual dan keyakinan, tetapi juga ke arah akhlak sosial dan kemanusiaan, sehingga keniscayaan pluralisme dan multikulturalisme yang dipahami dengan sehat oleh anak didik secara profesional dan proporsional (Barizi, 152-153).

Pendidikan Islam berwawasan multikultural adalah gerakan pembaharuan dan inovasi pendidikan agama dalam rangka menanamkan kesadaran pentingnya hidup bersama dalam keragaman dan perbedaan agama-agama, dengan spirit kesetaraan dan kesederajatan, saling percaya, saling memahami dan menghargai persamaan, perbedaan dan keunikan agama-agama, sehingga terjalin dalam suatu relasi dan interdependensi dalam situasi saling mendengar dan menerima perbedaan perspektif agama-agama dalam satu dan lain masalah dengan pikiran terbuka, untuk menemukan jalan terbaik mengatasi konflik antaragama 
dan menciptakan perdamaian melalui sarana pengampunan dan tindakan nirkekerasan (Baidhawy, 2005:84).

Dalam situasi konflik, pendidikan agama berwawasan multikultural hadir untuk menyuntikkan spirit dan kekuatan spiritual sebagai sarana integrasi dan kohesi sosial dan memberikan angin segar bagi kedamaian dan perdamaian. Konflik antaragama berarti mengangkangi nilai-nilai agama tentang persaudaraan (ukhwah albasyariah) dan persatuan universal umat manusia (unity of humankind). Sarana untuk saling menyalahkan terletak pada perbedaan imperatif antar komuitas, dan dengan bingkai subyektif (kebenaran prespektif golongan) kepentingan agama dan kepentingan komunitas keagamaan menjadi tumpang tindih (Thohir, 2006:144-145).

Menurut Baidhawy (2005:78-79) konflik antar agama mampu diredam manakala mampu menghadirkan pendidikan agama berwawasan multikultural, hal ini dikarenakan pendidikan tersebut memiliki karateristik; 1) belajar hidup dalam perbedaan; 2) rasa saling percaya; 3) saling memahami; 4) saling menghargai; 5) berfikir terbuka; 6) apresisasi dan interdepedensi; 7) resolusi konflik dan rekonsiliasi nirkekerasan. Dengan karakteristik ini akan memunculkan sikap toleran, empati dan simpati yang tidak hanya bersandar pada how to know, how to do, dan how to be akan tetapi juga how to live and work together with others. Bagi Zubaedi (2007:47) realitas perbedaan bukan berarti mustahil untuk dijembatani. Akan tetapi, terdapat kemungkinan terbukanya jalur komunikasi yang dialogis. Bukan untuk mempersamakan hal yang memang berbeda, tapi untuk saling bicara dan saling memahami. 
Uraian di atas memberikan pemahaman bahwa tujuan mendasar dari pendidikan Islam berwawasan multikultural sebagai jalan keluar dari simptom eksklusivisme dengan keterkaitan yang berlebihan terhadap simbol-simbol agama, sebagai alat dan kekuatan untuk legitimasi dengan memfungsikan agama sebagai satu cara dalam meminimalisir, meresolusi dan merekonsiliasi konflik yang akan atau terjadi, karena agama adalah sistem untuk menata makna individu didalam masyarakat (seperti etnisitas, ras, gender, daerah, dan suku) yang dapat mempengaruhi respons terhadap konflik yang terjadi berikut metode resolusinya entah itu positif maupun negatif (Nimer, 2010:6-7).

\section{Universalitas Islam melalui Pendidikan Islam Berwawasan Multikultural}

Salah satu kesadaran yang berakar kuat dalam pandangan seseorang muslim adalah Islam merupakan agama universal, agama untuk sekalian umat manusia. Sejarah menunjukkan, pandangan ini melahirkan sikap sosial-keagamaan yang unik dikalangan umat Islam terhadap agamaagama lain atas dasar toleransi, kebebasan, keterbukaan, kewajaran, keadilan dan kejujuran. Inilah manifestasi konkret nilai-nilai madani yang terbukti pernah menjadi pilar tegaknya masyarakat madani, sebagaimana diuraikan Kartanegara (2007:80-91) tentang nilai-nilai madani yang menyokong tegaknya masyarakat kosmopolit, meliputi; pertama, inklusivisme, yaitu keterbukaan diri terhadap "unsur luar" melalui kemampuan melakukan apresiasi dan seleksi secara konstruktif. Kedua, humanisme, dalam artian cara pandang yang memperlakukan 
manusia semata-mata karena kemanusiaannya, tidak karena sebab lain di luar itu, semisal ras, kasta, kekayaan, dan agama, termasuk sikap egaliter yang memandang manusia sama derajatnya. Ketiga, toleransi, yaitu adanya kelapangdadaan dan kebesaran jiwa dalam menyikapi perbedaan. Keempat, demokrasi yang memberi ruang bagi kebebasan berfikir dan penyampaian kritik.

Dalam konteks hidup bermasyarakat dan bernegara yang plural, tipe keberagamaan yang menekankan orientasi kemanusiaan perlu mendapat apresiasi dan penekanan. Setidaknya terdapat tiga hal yang menegaskan Islam sebagai agama yang mengusung misi kemanusiaan; 1) Islam adalah agama yang berpijak pada konsep fitrah, dengan fitrahnya, manusia berkesiapan mengenal Tuhannya dan mengembangkan kemanusiaannya karena telah dibekali potensi diri sedari lahir; 2) Islam adalah agama yang mempunyai semangat toleransi yang tinggi, yang bersifat moderat, adil, dan jalan tengah, prinsip ini menjadi pondasi umat Islam dalam membangun tata kehidupan harmonis, baik dalam intraagama maupun interagama dengan mengedepankan dialog dan perdamaian; 3) Islam adalah agama yang mengutamakan kemaslahatan dan menghindari kemudaratan (Misrowi, 2010:52-55).

Dengan melibatkan Islam dalam pendidikan multikultural, maka agama akan mampu berperan secara maksimal, yang tidak lagi hanya menanamkan kesalehan ritual, tapi juga melakukan yang lebih penting dari itu yaitu mewujudkan kesalehan sosial yang mampu membongkar proses dehumanisasi (Baidhawy, 2005:74-135). Hal ini disebabkan, peran sosial agama ditandai oleh fungsinya dalam menjaga integrasi 
sosial. Dalam fungsi itu agama berusaha mengurangi perbedaan dan pertentangan diantara berbagai kelompok dan berbagai individu, agar terhindar dari kemungkinan konflik sosial yang dapat membawa kepada disintegrasi sosial atau bahkan nasional (Sinaga, ed., 2000:28). Konflik yang terjadi di Indonesia dikarenakan agama belum dioptimalkan perannya, yang terbangun saat ini hanya aspek kognitif yang melahirkan doktrin kaku dan konservatif yang menjadi dasar legitimasi segenap perbuatannya, maka wajar solidaritas hanya berlaku bagi kelompok yang sepaham atau aliran (Mariani, 2013:2-3). Uraian dan penjelesan ini menegaskan bahwa memang terdapat hubungan yang kuat antara nilainilai (agama) dalam kebangsaan, yang berpijak pada semangat humanitas dan universalitas Islam, melalui kedua landasan ini akan memunculkan keberagaman yang inklusif (Sulalah, 2011:75). Sebagai upaya untuk memahami kebenaran yang lain dan pembaharuan hidup dalam bingkai kebersamaan dengan membiarkan ruang terbuka bagi munculnya kebebasan positif bagi setiap individu manusia (Gellner, 2009:73).

Pendidikan multikultural dalam Islam berarti penjabaran nilainilai yang terdapat dalam al-Qur'an dan Sunah ke dalam bentuk gagasan, materi, tingkah laku, dan norma, yang bertujuan untuk membumikan ajaran Islam di tengah-tengah masyarakat, sehingga umat Islam dapat memahami dan mengkaji agama sebagai ungkapan kebutuhan makhluk budaya dan makhluk sosial. Dengan mengamalkannya, berarti seorang muslim telah melaksanakan ajaran agamanya sesuai dengan kulturnya, yaitu dengan berbuat baik melalui perbuatan yang ma'ruf; sebagai perbuatan yang didasarkan pada kebaikan bersama dan dia meyakininya, 
dan meninggalkan yang mungkar; sebagai perbuatan yang didasarkan pada keburukan secara rasional maupun sosial (Usman, t.t.:25-26). Menurut Usman (t.t.:61), seseorang akan semakin menjauh terhadap Tuhannya, jika hanya memperhatikan aspek vertikal saja; seperti sholat, puasa, hidup zuhud, karena Tuhan memerintah hambanyanya untuk mengaplikasikan Ibadah dalam bentuk perbuatan sosial "horizontal". Dengan pendidikan multikultural, ini berarti ajaran Islam membentuk jalan kedamaian dan kebersamaan dalam bingkai kerukunan sebagai wujud pengembangan solidaritas sesama umat manusia berdasarkan keimanan dan ketakwaannya (Imārah, 1985:18-23).

Ajaran Islam mudah diterima dan kewajiban-kewajiban yang ditetapkan sesuai dengan kemampuan orang yang normal. Begitu pula, Islam tidak menyuruh seseorang untuk mempercayai sesuatu yang bertentangan dengan akal. Ajaran Islam menyeimbangkan antara kepentingan individu dan kepentingan masyarakat, tidak mengutamakan kepentingan individu dan mengorbankan kepentingan masyarakat atau sebaliknya (Imārah, 1998:12-14). Solidaritas dan persatuan bukan hanya merupakan kewajiban sosial, tetapi juga merupakan kewajiban agama yang harus diwujudkan. Terbinanya solidaritas di kalangan umat Islam berarti terbukanya kesempatan bagi mereka untuk memikirkan masalahmasalah yang berhubungan dengan berbagai aspek di luar masyarakat Islam (Zahroh, 1991:7-11). Pendidikan Islam, keberadaannya berperan membentuk karakter-karakter individu sebagai insān kāmil (manusia paripurna). sehingga tuntutan reformasi sistem pendidikan Islam yang 
terkesan sebagai alat indoktrinasi yang anti realitas multikultural perlu dilakukan.

\section{Ultimate Goal Pendidikan Islam Berwawasan Multikultural; Manifestasi Manusia Cerdas sebagai Insan Kamil}

Pendidikan Islam berwawasan multikultural mampu menampilkan ekspresi Islam yang sesuai dengan al-Qur'an, baik dalam pemikiran, perbuatan, dan persekutuan (fellowship) atau keummatan, yaitu sebuah ekspresi yang memberikan kebaikan yang nyata bagi kehidupan, khususnya manusia (Barizi, 2011:153-154). Islam yang Qur'ani adalah Islam mengusung kebaikan untuk kebersamaan sesama ummat manusia, dengan membebaskan manusia dari kebodohan, kemiskinan dan keterbelakangan, inilah yang menjadi misi Nabi dalam risalahnya sebagai rahmat dan bukan menjadi pelaknat semua umat manusia (Ilyas, 2007:63). Sedangkan multikulturalisme memandang bahwa adanya keanekaragaman, perubahan dan konflik sebagai sesuatu yang positif untuk memperkaya spiritualitas dan memperkuat iman, keluar dari batas keberpihakan yang destruktif, melintasi batas konflik untuk memberikan solusi alternatif yang mencerdaskan dan mencerahkan (Mahfud, 2006:104-106). Bagi pemikiran posmodernisme tidak ada benturan kebudayaan (kultur), yang ada adalah ruang toleransi yang mengharuskan koeksistensi antar kebudayaan dan peradaban (Tilaar, 2004:176).

Pendidikan Islam berwawasan multikultural dapat diartikan sebagai suatu bentuk respek yang bersifat mutual dari satu etnik kepada etnik lain, dengan memberikan keleluasaan agar dapat mengekspresikan 
budayanya, sebagai salah satu kontribusi bagi pengembangan budaya suatu bangsa (Liliweri, 2005:68). Dengan demikian, Pendidikan Islam berwawasan multikultural bukanlah suatu pandangan yang tidak menutup diri terhadap budaya lain namun mengharuskan adanya dialog dan toleransi dengan budaya-budaya yang lain, dengan duduk sama tinggi dan berdiri sama rendah, mampu melihat keaneragaman budaya sebagai realitas fundamental dalam kehidupan bermasyarakat, membuka diri untuk menjalani kehidupan bersama dengan melihat realitas plural sebagai kemestian hidup kodrati (Tilaar, 2004:176). Dengan dasar ini, peserta didik dapat menolong bangsanya keluar dari perbedaan penghayatan dan penglihatan antara idealisme dengan realitas, dan mampu membawa kerukunan dan perdamaian, tanpa ada konflik dan kekerasan, meski terdapat kompleksitas perbedaan (Zubaedi, 2007:58).

Universalitas merupakan karakteristik Islam, yang sejak awal para pemeluknya tidak hanya berasal dari bangsa Arab, tetapi juga bangsa-bangsa diluar Arab yang sudah mendengar dakwah Nabi Muhammad, seperti Shuhaib ar-Rumi dan Salman al-Farisi yang berkebangsaan Romawi dan Persia. Selanjutnya penerimaan Nabi Muhammad terhadap budaya lain, seperti penerimaannya untuk menerangi masjid dengan lampu minyak yang diusulkan Tamim ad-Dari yang mendapat inspirasi dari praktek di Gereja Kristen, dan penerimaannya menggunakan strategi penggalian parit (perang khandaq) di sekeliling madinah untuk menghadang musuh, yang diusulkan oleh Salman al-Farisi yang terinspirasi dari praktek perang Bangsa Persia (Ilyas, 2007:65). Untuk itulah ajaran Islam lebih bersemangat 
mengandung unsur inklusif dalam bingkai rahmatan lil 'alamin (rahmat bagi seluruh alam) yang menjadi sikap dasar mayoritas umat Islam, sehingga mampu hidup berdampingan secara damai dan bekerjasama dengan pemeluk agama lain atas dasar saling memahami, menghargai, dan mempercayai. Sikap dasar tersebut dipandang sejalan dengan basis teologis, bahwa 1) kemajemukan merupakan sunnah Tuhan; 2) pengakuan hak eksistensi agama-agama lain; 3) titik temu atau kontinuitas agama-agama (kalimatun sawā'); dan 4) tidak ada paksaan dalam agama (Majid, 2000:177-179).

Pendidikan multikultural bertujuan agar terciptanya bangsa yang memiliki integritas tinggi, bangsa maju, berperadaban disegani oleh bangsa lain dalam framework global-multikultural. Di Indonesia tujuan tersebut diwujudkan dengan pengembangan pada dimensi individual yang diproyeksikan dengan konsep manusia Indonesia cerdas, yaitu manusia yang menguasai dan memanfaatkan ilmu pengetahuan dengan sebaik-baiknya untuk peningkatan mutu kehidupan, baik sebagai perseorangan maupun sebagai kelompok, dan sebagai anggota masyarakat dan bangsanya. Manusia cerdas memiliki ciri sebagai profil manusia yang bermoral, beriman, inklusif, tidak membenarkan apa yang dimilikinya, cita-citanya, agamanya, ideologi politiknya untuk dipaksakan kepada orang lain (Tilaar, 2004:103-105).

Sementara itu dalam pendidikan Islam, karakteristik manusia Indonesia cerdas dilafalkan dengan Insān kāmil, yaitu manusia paripurna, yang memiliki budi pekerti luhur dan akhlak yang sempurna, sebagai manusia yang beriman dan bertaqwa kepada Allah. Insān kāmil adalah 
gambaran manifestasi manusia yang mampu menunaikan tugas dan kewajibannya selaku makhluk Allah sebagai khalifah di bumi, mampu menjalankan dan membagun tugas kemasyarakatan, kebangsaan, keagamaan secara bersama-sama membangun peradaban Islam dan tugas-tugas dalam membangun kehidupan bersama secara integral dengan sebaik-baiknya sesuai dengan prinsip-prinsip kehidupan menurut al-Qur'an dan Sunnah (Mashadi, 2009:37-39). Penjelasan di atas mempertegas bahwa pendidikan multikultural dengan konsep manusia cerdas dan pendidikan Islam dengan konsep insān kāmil, memiliki misi yang sama dalam menggambarkan profil manusia yang beriman dan bertakwa kepada Allah (religius), cerdik-pandai, energik-kreatif, responsif terhadap masyarakat demokratis, memiliki ketrampilan (skilled), berakhlak mulia (moralis), dan berperadaban (civillized).

Konteks pendidikan Islam berwawasan multikultural ini berarti bahwa setiap peserta didik mempunyai hak untuk masuk dalam budaya tertentu, dan ikut serta dibentuk dan membentuk budaya itu. Sebagai lahan untuk menghapus prasangka, dan sekaligus untuk melatih dan membangun karakter siswa agar mampu bersikap demokratis, humanis dan pluralis. Pendidikan Islam berwawasan Multikultural hadir bertujuan untuk membangun keberagaman siswa yang inklusif dan moderat serta mengeliminir jarak sosial antar peserta didik yang berbeda agama guna terciptanya persaudaraan sejati (Yusuf, ed., 2008:2). Oleh karena itu, pendidikan Islam berwawasan multikultural mengajarkan bagaimana cara hidup ditengah pluralisme bangsanya, agar mereka mampu hidup, baik dalam internal kelompoknya maupun eksternal kelompok lain, dapat 
hidup damai dengan lingkungannya, memaknai perbedaan yang dibingkai dalam bhinneka tunggal ika secara bijaksana dan tepat untuk menjadi manusia cerdas dalam prespektif pendidikan multikultural dan insan kamil dalam pendidikan Islam. Waallahu 'Alam.

\section{Simpulan}

Pendidikan Islam berwawasan multikultural lahir karena realitas multikulturalisme yang ada pada masyarakat multikultur seperti Indonesia, walaupun memberikan sumbangan besar bagi munculnya ketegangan, konflik dan krisis sosial, Namun, bila dikelola dengan benar, arif, bertanggung jawab dan penuh toleransi, perbedaan dan keragaman akan menjadi hal yang bermanfaat bagi bangsa Indonesia. Tujuan pendidikan multikultural diproyeksikan dengan konsep manusia Indonesia cerdas, yaitu kondisi seseorang yang mampu memanfaatkan keragaman dan perbedaan menjadi hal yang positif bagi perkembangan dirinya dan orang lain. Hal ini termanifestasikan dalam konsep pendidikan Islam melalui Insān Kāmil yaitu manusia paripurna memiliki budi pekerti luhur, beriman dan bertakwa, dan mampu menjalankan tugas dan kewajiban vertikal maupun horizontalnya.

Islam memperkokoh toleransi dan memberikan aspirasi terhadap multikulturalisme, dan menegaskan terdapat hubungan yang kuat antara nilai-nilai (agama) dalam kebangsaan dengan dilandasi semangat humanitas dan universalitas Islam. Dengan melibatkan agama dalam pendidikan multikultural, maka agama akan mampu berperan secara maksimal, yang tidak lagi hanya menanamkan kesalehan ritual, tetapi 
juga mewujudkan kesalehan sosial. Oleh karenanya pendidikan agama berwawasan multikultural, hadir diproyeksikan sebagai gerakan pembaharuan dan inovasi pendidikan agama dalam rangka menanamkan kesadaran pentingnya hidup bersama dalam keragaman dan perbedaan, dengan spirit kesetaraan dan kesederajatan, saling percaya, saling memahami dan menghargai persamaan, perbedaan dan keunikan agama, sehingga terjalin dalam suatu relasi dan interdependensi dalam menciptakan perdamaian.

\section{Daftar Pustaka}

An-Nahlawiy, A. (1989). Prinsip-prinsip dan Metode Pendidikan Islam, dalam Keluarga, di Sekolah dan di Masyarakat, terj. Dahlan dan Soelaeman. Bandung: Cv. Diponegoro.

At-Toumy, O. M. (1979). Falsafah Pendidikan Islam. Jakarta: Bulan Bintang.

Asifudin, A. J. (2009). Mengungkit Pilar-Pilar Pendidikan Islam; Sebuah Tinjauan Filosofis. Yogyakarta: Sunan Kalijaga Press.

As-Sabt, H̄. U. (t.t.). Al-Amru bi Al-Marūf Wa An-Nahyu 'An AlMungkar. T.tp: Silsilah tasdir an Al-Muntadī al-Islamī.

Ata Ujan, A., dkk. (2009). Multikulturalisme: Belajar Hidup Bersama dalam Perbedaan. Jakarta: PT. Indeks.

Azra, A. (1999). Esei-Esei Intelektual Muslim dan Pendidikan Islam. Jakarta: PT. Logos Wacana Ilmu.

Baidhawy, Z. (2005). Pendidikan Agama Berwawasan Multikultural. Jakarta: Erlangga.

Banks, J. \& Banks, C. A. M. (2010). Multicultural Education; Issues and Perspectives, 7nd edition, New York: Jhon Wiley and Sons.

Barizi, A. (2011). Pendidikan Integratif; Akar Tradisi dan Integrasi Keilmuan Pendidikan Islam. Malang: UIN Maliki Press.

Esposito, J. L. (2004). Islam Warna-Warni: Ragam Ekspresi Menuju "Jalan Lurus" (al-Shirāt al-Mustaqīm). Jakarta: Paramadina. 
Farida, A. (2011). Dakwah Multikultural Untuk Merajut Kerukunan dan Perdamaian, dalam dalam Jurnal PENAMAS, Vol. XXIV, No. 1, 2011. Jakarta: BALITBANG Kemenag RI.

Ghozali, M. (2005). Khuliqu al-Muslim, Mesir: Nahḍah Mesr.

Helmatiana, K. (2004). Pluralisme dan Inklusivisme Islam di Indonesia, Jakarta: PBB UIN Syarif Hidayatullah \& Konrad Adenauer Stiftung.

Ilyas, H. (2007). Paradigma dan Karakteristik Islam Sebagai Rahmat Untuk Semua, dalam Belajar dari Kisah Kearifan Sahabat: Ikhtiar Pengembangan Pendidikan Islam, Yogyakarta: Pilar Media.

Imarah, M. (1985). Al-Islām wa Huqūq Al-Insān; Darūrāt Lā Huqūq, Kuwait: Majlis Al-Waṭoni Li As-Syaqofah wa al-Funūn wal adāb.

Imarah, M. (1998). Al-Islam wa Al-Am'n al-Ijtima î. Kairo: Dār AsSyurūq.

Ismail, dkk, (ed.). (2001). Paradigma Pendidikan Islam. Yogyakarta: Pustaka Pelajar.

Kusmana. (2004). Ham Prespektif Al-Qur'an dan Hadis, Jakarta: PBB UIN Syarif Hidayatullah \& Konrad Adenauer Stiftung.

Kyimlicka, W. (2003). Multicultural Citizenship; A liberal Theory of Minority Right. Oxford: Clarendon Press.

Langgulung, H. (1995). Manusia dan Pendidikan; Suatu Analisa Psikologi Pendidikan. Jakarta; PT. Al-Husa Zikra.

Liliweri, A. (2005). Prasangka dan Konflik; Komunikasi Lintas Budaya Masyarakat Multikultur. Yogyakarta: PT. LkiS Pelangi Aksara.

Lubis, A. Y. (2006). Dekonstruksi Epistemologi Moderen. Jakarta: Pustaka Indonesia Satu.

Mahfud, C. (2006). Pendidikan Multikultural. Yogyakarta: Pustaka Pelajar.

Majid, N. (2000). Islam, Doktrin Dan Peradaban. Cet. Ke-IV. Jakarta: Paramadina.

Mashadi, I. (2009). Reformasi Pendidikan Agama Islam (PAI) di Era Multikultural dalam Pendidikan Agama Islam dalam Prespektif Multikulturalisme. Jakarta: Balitbang Kemenag RI.

Mariani, N. (2013). Ahmadiyah, Conflict, and Violence in Contemporary Indonesia Dalam Indonesian Jurnal Of Islam and Muslim Societies Vol. 3. Number 1, June. STAIN Salatiga.

Marimba, A. D. (1980). Pengantar Filsafat Pendidikan Islam, Bandung; al-Ma'arif. 
Mc.Neil, J. D. (1988). Kurikulum: Sebuah Pengantar Komprehenship, terj. Subandiah, Jakarta: Bulan Bintang.

Misrawi, Z. (2010). Al-Qur'an Kitab Toleransi; Tafsir Tematik Islam Rahmatan Lil 'Alamin. Jakarta: Pustaka Oasis.

Muqowim. (2007). Epistemologi Pendidikan Islam Dalam Konteks Masyarakat Majemuk dalam Belajar dari Kisah Kearifan Sahabat; Ikhtiar Pengembangan Pendidikan Islam. Yogyakarta; Pilar Media.

Nasution, S. (2003). Asas-Asas Kurikulum. Jakarta: Bumi Aksara.

Race, R. (2011). Multiculturalism and Education: Contemporary Issues in Education Studies. New York: Continuum International Publishing.

Sulalah. (2011). Pendidikan Multikultural; Didakta Nilai-Nilai Universalitas Kebangsaan. Malang: UIN Maliki Press.

Sumartana, T. H., dkk. (2001). Pluralisme, Konflik dan Pendidikan Agama di Indonesia. Yogyakarta: Pustaka Pelajar.

Sinaga, M. L. (2000). Agama Memasuki Melenium Ketiga, Jakarta: Garsindo.

Tilaar, H. A. R. (2004). Multikulturalisme; Tantangan-tantangan Global Masa Depan Dalam Transformasi Pendidikan Nasional. Jakarta: Grasindo.

Yusuf, C. F., (ed.). (2008). Eksperimen Pendidikan Agama Berwawasan Kerukunan. Jakarta: Pena Citasatria.

Zubaedi. (2007). Islam; Benturan dan Antar Peradaban. Yogyakarta: Arruzz Media.

Zahrah, A. M. (1991). At-Takāful al-Ijtimā' $̄$ F̌̀ al-Islām. Mesir: Dār AlFikr al-'Arabī. 